\title{
DIETS OF THREE SPECIES OF BUFONIDS (AMPHIBIA, ANURA) FROM NORTHERN MEXICO
}

\author{
Geoffrey R. Smith ${ }^{1,3}$, Julio A. Lemos-Espinal ${ }^{2}$, Allison B. Burner ${ }^{1}$, \\ Kristen E. Winter ${ }^{1}$, and Christopher B. Dayer ${ }^{1}$
}

\begin{abstract}
We examined the diets of 3 species of bufonids from northern Mexico (Anaxyrus debilis, Anaxyrus punctatus, and Incilius mazatlanensis) with the objective of better understanding the diets of amphibians in this region of Mexico, which is currently undergoing environmental change. The diet of A. debilis was numerically and volumetrically dominated by termites, followed by ants. In A. debilis, some aspects of prey size were correlated with toad head width but were not related to head length or body size (i.e., snout-vent length [SVL]). Ants were numerically the most important prey item in the diet of A. punctatus, but beetles were volumetrically the most important prey item. Prey size was not related to toad head size or body size in A. punctatus. The diet of I. mazatlanensis numerically consisted of ants, beetles, and bugs; however, volumetrically, its diet was dominated by beetles. In I. mazatlanensis, only prey length was correlated with toad head width and SVL. The diets of these 3 species generally fit our previous understanding of the diets of bufonids.
\end{abstract}

Resumen.-Examinamos la dieta de 3 especies de bufónidos del norte de México (Anaxyrus debilis, Anaxyrus punctatus e Incilius mazatlanensis) con el objetivo de entender mejor la dieta de los anfibios en esta región de México que actualmente experimenta un cambio ambiental. La dieta de A. debilis fue dominada numérica y volumétricamente por las termitas, seguidas por las hormigas. En A. debilis, algunos aspectos del tamaño de sus presas estuvieron correlacionados con el ancho de la cabeza pero no estuvieron relacionados con el largo de la cabeza ni con el tamaño del cuerpo. Numéricamente, las hormigas fueron la presa más importante en la dieta de A. punctatus, pero los escarabajos fueron la presa más importante de acuerdo al volumen. El tamaño de la presa no estuvo relacionado con el tamaño de la cabeza o el cuerpo de los sapos en la dieta de A. punctatus. Numéricamente, la dieta de I. mazatlanensis consistió principalmente de hormigas, escarabajos e insectos; sin embargo, su dieta fue dominada volumétricamente por escarabajos. En I. mazatlanensis, solo el largo de la presa estuvo correlacionado con el ancho de la cabeza de los sapos y con su LHC (longitud hocico-cloaca). Las dietas de estas 3 especies corroboran en general nuestro entendimiento previo de las dietas de los bufónidos.

Analysis of diet breadth may provide some indication of how a species might be able to respond to changes in the prey community that might be associated with environmental change. For example, conversion of natural ecosystems to agricultural ecosystems or the invasion of areas by alien plants or animals can alter the insect community and thus affect the diets of insectivores, such as amphibians or reptiles (e.g., Dunn 2004, Rand and Louda 2006, Davis et al. 2008, Tallamy et al. 2010). Therefore, a basic understanding of a species' diet may be useful in considering the conservation or management of that species (Solé and Rödder 2010).

Some species of bufonids have been described as dietary generalists (e.g., de Carvalho Batista et al. 2011) and others as specialists on ants or termites (e.g., Isacch and Barg 2002, Santana and Juncá 2007). While we know the diets of several bufonids in the genus Anaxyrus, particularly species from the northern parts of the range in the United States and Canada, gaps still remain in our knowledge of the diets of Anaxyrus from Mexico (Table 1). In addition, we know far less about diets in the bufonid genus Incilius (Table 1). Here, we examine the diets of 3 species of bufonids (Anaxyrus debilis, Anaxyrus punctatus, and Incilius mazatlanensis) from northern Mexico, an area that has undergone and that continues to undergo environmental changes associated with overgrazing (Bryant et al. 1990, Mata-González et al. 2007, Sánchez Flores and Yool 2007), conversion to agriculture (Doolittle 2006, Macías-Duarte et al. 2009, Franklin and Molina-Freaner 2010), and climatic changes (e.g., decrease in precipitation; Villers-Ruiz and Trejo-Vázquez 1998, Serrat-Capdevila et al. 2007, Kimball et al. 2010). To our knowledge, the diets of these 3 species have not been previously described.

${ }^{1}$ Department of Biology, Denison University, Granville, OH 43023

${ }^{2}$ Laboratorio de Ecología, Unidad de Biotecnología y Prototipos, Facultad de Estudios Superiores Iztacala, UNAM, Avenida de Los Barrios No. 1, Los Reyes Iztacala, Tlalnepantla, Estado de México, 54090 México.

${ }^{3} \mathrm{E}$-mail: smithg@denison.edu 
TABLE 1. Review of the diets of bufonids in the genera Anaxyrus and Incilius. Order of diet items in column 2 reflects the items' order of importance as reported in the original study.

\begin{tabular}{lll}
\hline Species & Prey of importance & Reference \\
\hline A. americanus & Ants, beetles & Smith and Bragg 1949 \\
& Diptera, mites, ants, beetles & Hamilton 1930 \\
A. boreas & Ants, beetles & Schonberger 1945, Campbell 1970 \\
A. cognatus & Beetles, ants, Lepidoptera & Smith and Bragg 1949 \\
A. compactilis & Beetles, ants, Lepidoptera & Smith and Bragg 1949 \\
A. fowleri & Ants, beetles & Brown 1974, Clarke 1974 \\
& Beetles, ants & Bush and Menhinich 1962, Klimstra and Myers 1965 \\
A. hemiophrys & Beetles, ants & Moore and Strickland 1954 \\
A. quercicus & Ants, beetles & Hamilton 1955 \\
& Ants, spiders, termites, beetles & Punzo 1995 \\
A. terrestris & Ants, beetles & Meshaka and Mayer 2005 \\
& Beetles, ants, termites, spiders & Punzo 1992 \\
A. woodhousei & Beetles, Lepidoptera, ants & Smith and Bragg 1949 \\
I. alvarius & Beetles & Bogert and Oliver 1945 \\
I. coccifer & Beetles, ants & Greding and Hellebuyck 1980 \\
I. nebulifer & Termites, ants (numerically), & Santana and Juncá 2007 \\
& Orthoptera (volumetrically) & \\
\hline
\end{tabular}

We provide information on the composition of the diets, as well as the relationships between measures of toad size and prey size, with the objective of better understanding the diets of amphibians in this region of Mexico.

We examined specimens of A. debilis $(n=$ $32)$, A. punctatus $(n=23)$, and I. mazatlanensis $(n=21)$ from the collection of the Laboratorio de Ecología, UBIPRO-FES-Iztacala, UNAM (see Lemos-Espinal et al. 2004 and Smith et al. 2005 for details of collection). The A. debilis specimens were collected in summer and fall 2004 from a locality in Coahuila at an elevation of $114 \mathrm{~m}$, with one specimen coming from Chihuahua at an elevation of 1427 m (Appendix). The A. punctatus specimens were pooled from collections made in the summer of 2003 and the summer and fall of 2004 from several localities in Sonora, Chihuahua, and Coahuila, ranging in elevation from $435 \mathrm{~m}$ to $1545 \mathrm{~m}$ (Appendix). The I. mazatlanensis specimens were collected in summer 2003 and in summer and fall 2004 from 3 localities in Sonora and 2 localities in Chihuahua, ranging in elevation from $435 \mathrm{~m}$ to $1545 \mathrm{~m}$ (Appendix). Specimens were preserved in formalin within 30 minutes of collection; thus, the effects of digestion on observed stomach contents were likely minimal.

We measured snout-vent length (SVL) of each specimen using a clear plastic ruler (to nearest $\mathrm{mm}$ ). We measured head width (HW; at corner of mouth) and head length (HL; from corner of mouth to tip of nose) using a digital caliper (to nearest $0.01 \mathrm{~mm}$ ). We dissected specimens to remove the stomach. Stomach contents were identified to the lowest taxonomic level possible and counted. We measured the length and width of each prey item using a digital caliper (to nearest $0.01 \mathrm{~mm}$ ) and calculated prey volume using the volume of a prolate spheroid. We used BugRun software to calculate niche breadth based on prey number and prey volume (Vitt and Zani 2005). We calculated importance values for each prey category using the sum of the percent prey volume, percent prey number, and percent of stomachs that contained the prey item (Powell et al. 1990). We used linear regression to examine the relationships among morphological variables (SVL, HW, HL) and prey size (width, length, volume), stomach volume, and number of prey consumed.

\section{Anaxyrus debilis}

Of the 32 stomachs examined, 30 contained identifiable prey items, and 2 contained unidentifiable prey items. Mean SVL was $4.20 \mathrm{~cm}$ $(\mathrm{SE}=0.11, n=32)$. The $\operatorname{diet}$ of $A$. debilis was numerically and volumetrically dominated by termites, followed by ants (Table 2 ). The remaining prey items were also insects. Isopterans had a high importance value compared to all other prey items (Table 2). Niche breadth based on number of prey was 1.74 , and niche breadth based on volume of prey was 1.25.

Mean prey width, length, and volume were not not significantly related to HL or SVL. However, mean prey width, length, and volume did have significant positive relationships with HW. Number of prey per stomach was not related to SVL, and prey volume per stomach was not 
TABLE 2. Diet of 30 Anaxyrus debilis from northern Mexico. IV = importance value.

\begin{tabular}{lrrcrrrr}
\hline Prey taxon & Number & \% Number & Volume $\left(\mathrm{cm}^{3}\right)$ & \% Volume & Stomachs & \% Stomachs & IV \\
\hline $\begin{array}{l}\text { Coleoptera } \\
\quad \text { Adult }\end{array}$ & 10 & 0.68 & 0.16 & 0.68 & 6 & 20 & 21.36 \\
$\quad$ Larvae & 13 & 0.88 & 0.03 & 0.13 & 1 & 3.33 & 4.34 \\
Diptera & 55 & 3.74 & 1.5 & 6.4 & 10 & 33.3 & 43.44 \\
Hymenoptera & & & & & & \\
$\quad$ Formicidae & 323 & 21.94 & 0.61 & 2.6 & 18 & 30 & 84.54 \\
$\quad$ Apidae & 2 & 0.14 & 0.1 & 0.43 & 1 & 3.9 & 3.33 \\
$\quad$ Other & 4 & 0.27 & 0.1 & 0.43 & 1 & 4.03 \\
Isoptera & 1065 & 72.35 & 20.93 & 89.33 & 25 & 83.3 & 244.98 \\
\hline
\end{tabular}

TABLE 3. Relationships of prey attributes with head length (HL), head width (HW), and snout-vent length for 3 bufonid species. Sample size, coefficient of determination, and probability values are given for each linear regression model; $\alpha=0.05$.

\begin{tabular}{|c|c|c|c|c|}
\hline Species and model & $n$ & $r^{2}$ & $P$ & Regression equation \\
\hline \multicolumn{5}{|l|}{ Anaxyrus debilis } \\
\hline prey width vs. HL & 30 & 0.107 & 0.078 & \\
\hline prey length vs. HL & 30 & 0.057 & 0.20 & \\
\hline prey volume vs. HL & 30 & 0.089 & 0.11 & \\
\hline prey width vs. HW & 30 & 0.149 & 0.035 & Prey width $=-0.043+0.152 \mathrm{HW}$ \\
\hline prey length vs. HW & 30 & 0.13 & 0.05 & Prey length $=0.030+0.401 \mathrm{HW}$ \\
\hline prey volume vs. HW & 30 & 0.20 & 0.013 & Prey volume $=-0.034+0.033 \mathrm{HW}$ \\
\hline prey width vs. SVL & 30 & 0.001 & 0.90 & \\
\hline prey length vs. SVL & 30 & 0.029 & 0.37 & \\
\hline prey volume vs. SVL & 30 & 0.017 & 0.50 & \\
\hline prey per stomach vs. SVL & 30 & 0.007 & 0.67 & \\
\hline prey volume per stomach vs. SVL & 30 & 0.044 & 0.26 & \\
\hline \multicolumn{5}{|l|}{ Anaxyrus punctatus } \\
\hline prey width vs. HL & 20 & 0.006 & 0.76 & \\
\hline prey length vs. HL & 20 & 0.058 & 0.30 & \\
\hline prey volume vs. HL & 20 & 0.029 & 0.47 & \\
\hline prey width vs. HW & 20 & 0.029 & 0.48 & \\
\hline prey length vs. HW & 20 & 0.018 & 0.58 & \\
\hline prey volume vs. HW & 20 & 0.007 & 0.72 & \\
\hline prey width vs. SVL & 20 & 0.10 & 0.16 & \\
\hline prey length vs. SVL & 20 & 0.003 & 0.83 & \\
\hline prey volume vs. SVL & 20 & 0.084 & 0.21 & \\
\hline prey per stomach vs. SVL & 20 & 0.084 & 0.21 & \\
\hline prey volume per stomach vs. SVL & 20 & 0.248 & 0.025 & Stomach volume $=-0.13+0.065 \mathrm{SVL}$ \\
\hline \multicolumn{5}{|l|}{ Incilius mazatlanensis } \\
\hline prey width vs. HL & 20 & 0.002 & 0.86 & \\
\hline prey length vs. HL & 20 & 0.008 & 0.72 & \\
\hline prey volume vs. HL & 20 & 0.032 & 0.45 & \\
\hline prey width vs. HW & 20 & 0.127 & 0.123 & \\
\hline prey length vs. HW & 20 & 0.233 & 0.031 & Prey length $=0.077+0.321 \mathrm{HW}$ \\
\hline prey volume vs. HW & 20 & 0.126 & 0.12 & \\
\hline prey width vs. SVL & 20 & 0.133 & 0.11 & \\
\hline prey length vs. SVL & 20 & 0.328 & 0.0083 & Prey length $=-0.005+0.129 \mathrm{SVL}$ \\
\hline prey volume vs. SVL & 20 & 0.125 & 0.13 & \\
\hline prey per stomach vs. SVL & 20 & 0.088 & 0.205 & \\
\hline prey volume per stomach vs. SVL & 20 & 0.007 & 0.73 & \\
\hline
\end{tabular}

related to SVL. Results for all models are given in Table 3.

\section{Anaxyrus punctatus}

Three of the 23 examined stomachs were empty. Mean SVL was $4.24 \mathrm{~cm}(\mathrm{SE}=0.28, n=$
23). Ants were numerically the most important prey item in the diet of A. punctatus, followed distantly by termites and beetles (Table 4). Volumetrically, beetles were the most important prey item, followed by ants (Table 4). Ants had the highest importance value followed relatively 
TABLE 4. Diet of 20 Anaxyrus punctatus from northern Mexico. IV = importance value.

\begin{tabular}{|c|c|c|c|c|c|c|c|}
\hline Prey taxon & Number & $\%$ Number & Volume $\left(\mathrm{cm}^{3}\right)$ & $\%$ Volume & Stomachs & $\%$ Stomachs & IV \\
\hline Aranae & 1 & 0.24 & 0.01 & 0.23 & 1 & 5 & 5.47 \\
\hline \multicolumn{8}{|l|}{ Coleoptera } \\
\hline Adult & 34 & 8 & 2.28 & 52.41 & 13 & 65 & 125.41 \\
\hline Larvae & 1 & 0.24 & 0.03 & 0.69 & 1 & 5 & 5.93 \\
\hline Diptera & 1 & 0.24 & 0.02 & 0.46 & 1 & 5 & 5.7 \\
\hline Hemiptera & 1 & 0.24 & 0.07 & 1.61 & 1 & 5 & 6.85 \\
\hline Homoptera & 4 & 0.94 & 0.09 & 2.07 & 2 & 10 & 13.01 \\
\hline \multicolumn{8}{|l|}{ Hymenoptera } \\
\hline Formicidae & 329 & 77.41 & 1.41 & 32.41 & 16 & 80 & 189.82 \\
\hline Isoptera & 51 & 12 & 0.37 & 8.51 & 1 & 5 & 25.51 \\
\hline Lepidoptera (larvae) & 2 & 0.47 & 0.06 & 1.38 & 2 & 10 & 11.85 \\
\hline Mollusca (snail) & 1 & 0.24 & 0.01 & 0.23 & 1 & 5 & 5.47 \\
\hline
\end{tabular}

TABLE 5. Diet of 20 Incilius mazatlanensis from northern Mexico. IV = importance value.

\begin{tabular}{lrrrrrrr}
\hline Prey taxon & Number & \% Number & Volume $\left(\mathrm{cm}^{3}\right)$ & \% Volume & Stomachs & \% Stomachs & IV \\
\hline Coleoptera & 78 & 33.62 & 11.84 & 81.82 & 17 & 85 & 200.44 \\
Diptera & 1 & 0.43 & 0.29 & 2 & 1 & 5 & 7.43 \\
Hemiptera & 64 & 27.59 & 1.58 & 10.92 & 3 & 53.51 & 15 \\
Hymenoptera & & & & & & 35 & 75.08 \\
$\quad$ Formicidae & 84 & 36.21 & 0.56 & 0.9 & 2 & 10 & 11.76 \\
$\quad$ Apidae & 2 & 0.86 & 0.13 & 0.48 & 7 & 35 & 36.77 \\
Isoptera & 3 & 1.29 & 0.07 & & & & \\
\hline
\end{tabular}

closely by adult beetles (Table 4). Niche breadth based on prey number was 1.61, and niche breadth based on prey volume was 2.58 .

Mean prey width, length, and volume were not significantly related to HL, HW, or SVL. The number of prey per stomach was not related to SVL. Stomach volume increased with SVL. Model results are given in Table 3.

\section{Incilius mazatlanensis}

Twenty of the examined stomachs contained identifiable prey items, and one stomach contained unidentifiable prey items. Mean SVL was $6.18 \mathrm{~cm}(\mathrm{SE}=0.31 \mathrm{~cm}, n=21)$. The diet of I. mazatlanensis primarily consisted of ants, beetles, and bugs, at least numerically (Table 5). However, volumetrically, the diet was dominated by beetles (Table 5). Beetles also had the highest importance value, followed distantly by ants (Table 5). Niche breadth based on number of prey was 3.12, and niche breadth based on prey volume was 1.46 .

Mean prey width, length, and volume were not significantly related to HL. Mean prey width and volume were not significantly related to HW, but mean prey length was positively related to $\mathrm{HW}$. Mean prey width was not significantly related to SVL. Mean prey length was positively related to SVL. Mean prey volume and the number of prey per stomach were not related to SVL. Prey volume per stomach was not related to SVL. Model results are given in Table 3.

In general, niche breadths were relatively low in these 3 species of toads, although niche breadth varied somewhat depending on whether prey number or prey volume was used in the calculation. In any case, our results suggest that relatively few prey types were consumed by any single toad and the species as a whole. What is unclear is whether the low niche breadths are a consequence of prey selection on the part of the toads or a reflection of the availability of prey in the environment. For example, diet composition may reflect the relative availability of local prey (e.g., Hamilton 1955, Klimstra and Myers 1965, Boomsma and Arntzen 1985, de Carvalho Batista et al. 2011), although some species appear to select particular prey (Toft 1980, Teixeira et al. 1999, Isacch and Barg 2002, Santana and Juncá 2007). The low niche breadth suggests that environmental changes that could alter the prey community might have adverse effects on these toads; however, we need to know more about the relationship between diet and prey 
availability in these species to draw firmer conclusions.

Anaxyrus debilis ranges from Kansas south through the central plateau of Mexico (LemosEspinal and Smith 2007a, 2007b). Anaxyrus punctatus occurs from the southwestern U.S. south to the states of Jalisco and Hidalgo in Mexico (Lemos-Espinal and Smith 2007a, 2007b). Incilius mazatlanensis is relatively limited in its distribution, and only occurs in parts of Chihuahua, Colima, Jalisco, Nayarit, Sonora, and Sinaloa (Lemos-Espinal and Smith 2007a, Santos-Barrera et al. 2008). Given that I. mazatlantensis had the highest niche breadth based on prey numbers, A. punctatus had the highest niche breadth based on volume, and A. debilis had the lowest or near lowest niche breadths in both cases, there does not appear to be a relationship between geographic range and dietary breadth in these 3 species, at least in the pooled samples we examined.

Ants were an important prey item in all 3 species (A. debilis, A. punctatus, and I. mazatlanensis), at least from a numerical standpoint. However, termites were more important than ants in A. debilis, and volumetrically, beetles were more important than ants in I. mazatlanensis and A. punctatus. The importance values suggest that termites were the most important prey item in A. debilis, beetles were the most important prey item in I. mazatlanensis, and ants and beetles were both relatively important prey items in A. punctatus. Thus, while ants are numerically important in these species, it is misleading to consider them ant specialists since, from an energetic point of view, the taxa that were volumetrically more important were not ants. The diets we found in these species are similar to many other bufonid diets, and the variability among these 3 species reflects the variation within the family (Table 1). Duré et al. (2009) found that smaller species of bufonids appear to prefer ants, whereas larger species prefer beetles, suggesting prey choice may be related to body size. Indeed, our results tend to support this contention, at least in part: the largest species, I. mazatlantensis, consumed primarily beetles, whereas the 2 smaller species ate ants or termites relatively more than I. mazatlanensis.

We found that the relationships between prey size and toad head size or toad body size varied among the 3 species we studied. In A. debilis, prey size was correlated with head dimensions but was not related to body size. In I. mazatlanensis, only prey length was correlated with toad HW and toad SVL. Prey size was not related to toad head size or body size in A. punctatus. Our results, however, suggest that the relationship between prey size and toad body size in bufonids may not be generalizable and that other factors may drive diet composition in these species.

This study was supported by the Denison University Research Foundation and the Anderson Endowment of Denison University. We thank H.M. Smith for facilitating the loan of the specimens.

\section{Literature Cited}

Bogert, C.M., And J.A. Oliver. 1945. A preliminary analysis of the herpetofauna of Sonora. Bulletin of the American Museum of Natural History 83:297-426.

Boomsma, J.J., And J.W. Arntzen. 1985. Abundance, growth and feeding of natterjack toads (Bufo calamita) in a 4-year-old artificial habitat. Journal of Applied Ecology 22:395-405.

BRown, R.L. 1974. Diets and habitat preferences of selected anurans in southeast Arkansas. American Midland Naturalist 91:468-473.

Bryant, N.A., L.F. Johnson, A.J. Brazel, R.C. Balling, C.F. Hutchinson, And L.R. BEcK. 1990. Measuring the effect of overgrazing in the Sonoran Desert. Climatic Change 17:243-264.

Bush, F.M., And E.F. Menhinich. 1962. The food of Bufo woodhousei fowleri Hinckley. Herpetologica 18: $110-114$.

Campbell, J.B. 1970. Food habits of the boreal toad, Bufo boreas boreas, in the Colorado Front Range. Journal of Herpetology 4:83-85.

Clarke, R.D. 1974. Food habits of toads, genus Bufo (Amphibia: Bufonidae). American Midland Naturalist 91:140-147.

Davis, N.E., D.J. O’Dowd, P.T. Green, And R. MaCNALLY. 2008. Effects of an alien ant invasion on abundance, behavior and reproductive success of endemic island birds. Conservation Biology 22: 1165-1176.

de Carvalho Batista, R., C. Brito De-Carvalho, E. Borges de Freitas, S. da Cunha Franco, C. de Carvalho Batista, W. Araújo Coehlo, and R. Gomes FARIA. 2011. Diet of Rhinella schneideri (Werner, 1894) (Anura: Bufonidae) in the Cerrado, central Brazil. Herpetology Notes 4:17-21.

DoolitTLE, W.E. 2006. Agricultural manipulation of floodplains in the southern Basin and Range Province. Catena 65:179-199.

DunN, R.R. 2004. Managing the tropical landscape: a comparison of the effects of logging and forest conversion to agriculture on ants, birds, and Lepidoptera. Forest Ecology and Management 191:215-224.

Duré, M.I., A.I. Kehr, And E.F. Schaefer. 2009. Niche overlap and resource partitioning among five sympatric bufonids (Anura, Bufonidae) from northeastern Argentina. Phyllomedusa 8:27-39. 
Franklin, K., and F. Molina-Freaner. 2010. Consequences of buffelgrass pasture development for primary productivity, perennial plant richness, and vegetation structure in the drylands of Sonora, Mexico. Conservation Biology 24:1664-1673.

Greding, E.J., JR., And V.J. Hellebuyck G. 1980. Selection among five species of ecological separation by prey Central American anuran amphibians. Caribbean Journal of Science 16:23-31.

Hamilton, W.J., JR. 1930. Notes on the food of the American toad. Copeia 1930:45.

1955. Notes on the ecology of the oak toad in Florida. Herpetologica 11:205-210.

IsACCH, J.P., AND M. BARG. 2002. Are bufonid toads specialized ant-feeders? A case test from the Argentinian flooding pampa. Journal of Natural History 36: 2005-2012.

Kimball, S., A.L. Angert, T.E. Huxman, and D.L. VenABLE. 2010. Contemporary climate change in the Sonoran Desert favors cold-adapted species. Global Change Biology 16:1555-1565.

Klimstra, W.D., AND C.W. Myers. 1965. Foods of the toad, Bufo woodhousei fowleri Hinckley. Transactions of the Illinois Academy of Science 58:11-26.

Lemos-Espinal, J.A., AND H.M. SMith. 2007a. Anfibios y reptiles del estado de Chihuahua, México. CONABIO, Mexico City, México.

2007b. Anfibios y reptiles del estado de Coahuila México. CONABIO, Mexico City.

Lemos-Espinal, J.A., H.M. Smith, D. Hartman, and D. Chiszar. 2004. Selected year 2003 amphibians and turtles from Chihuahua and Sonora, Mexico. Bulletin of the Chicago Herpetological Society 39:107-109.

Macías-Duarte, A., A.B. Montoya, C.E. MÉndez-GonZÁLEZ, J.R. RodRÍGUEZ-SALAZAR, W.G. HunT, AND P.G. KRAnNitz. 2009. Factors influencing habitat use by migratory grassland birds in the state of Chihuahua, Mexico. Auk 126:896-905.

Mata-González, R., B. Figueroa-Sandoval, F. Clemente, AND M. ManZanO. 2007. Vegetation changes after livestock grazing exclusion and shrub control in the southern Chihuahuan Desert. Western North American Naturalist 67:63-70.

Meshaka, W.E., Jr., And A.L. MaYer. 2005. Diet of the southern toad (Bufo terrestris) from the southern Everglades. Florida Scientist 68:261-266.

Moore, J.E., And E.H. STRICKLAND. 1954. Notes on the food of three species of Alberta amphibians. American Midland Naturalist 52:221-224.

Powell, R., J.S. Parmerlee Jr., M.A. Rice, and D.D. Sмiтн. 1990. Ecological observations of Hemidactylus brookii haitianus Meerwarth (Sauria: Gekkoniae) from Hispaniola. Caribbean Journal of Science 26: $667-670$.

Punzo, F. 1992. Dietary overlap and activity patterns in sympatric populations of Scaphiopus holbrooki (Pelobatidae) and Bufo terrestris (Bufonidae). Florida Scientist 55:38-44.
1995. An analysis of feeding in the oak toad, Bufo graciosus (Holbrook), (Anura: Bufonidae). Florida Scientist 58:16-20.

RAND, T.A., AND S.A. LOUDA. 2006. Spillover of agriculturally subsidized predators as a potential threat to native insect herbivores in fragmented landscapes. Conservation Biology 20:1720-1729.

SÁNChez Flores, E., AND S.R. YOOL. 2007. Sensitivity of change vector analysis to land cover change in an arid ecosystem. International Journal of Remote Sensing 28:1069-1088.

Santana, A.S., AND F.A. JunCÁ. 2007. Diet of Physalaemus cf. cicada (Leptodactylidae) and Bufo granulosus (Bufonidae) in a semideciduous forest. Brazilian Journal of Biology 67:125-131.

Santos-Barrera, G., O. Flores-Villela, and P. PonceCAMPOS. 2008. Incilius mazatlanensis. IUCN Red List of Threatened Species. Version 2011.1.

SCHONBERGER, C.F. 1945. Food of some amphibians and reptiles of Oregon and Washington. Copeia 1945:120-121.

Serrat-Capdevila, A., J.B. Valdés, J. González Pérez, K. BAIRD, L.J. Mata, AND T. MADDOCK III. 2007. Modeling climate change impacts-and uncertainty-on the hydrology of a riparian system: the San Pedro Basin (Arizona/Sonora). Journal of Hydrology 347:48-66.

Smith, C.C., AND A.N. BragG. 1949. Observations on the ecology and natural history of anura. VII. Food and feeding habits of the common species of toads in Oklahoma. Ecology 30:333-349.

Smith, H.M., J.A. Lemos-Espinal, AND D. Chiszar. 2005. 2004 amphibians and lizards from Sonora, Chihuahua and Coahuila. Bulletin of the Chicago Herpetological Society 40:45-51.

SOLÉ, M., AND D. RÖDDER. 2010. Dietary assessments of adult amphibians. Pages 167-184 in C.K. Dodd Jr., editor, Amphibian ecology and conservation: a handbook of techniques. Oxford University Press, Oxford.

Tallamy, D.W., M. Ballard, and V. D’Amico. 2010. Can alien plants support generalist insect herbivores? Biological Invasions 12:2285-2292.

Teixeira, R.L., J.A.P. Schineider, And M. Giovanelli. 1999. Diet of the toad Bufo granulosus (Amphibia, Bufonidae) from sandy coastal plain in southeastern Brazil. Bol. Mus. Biol. Mello Leitão 10:29-31.

ToFT, C.A. 1980. Feeding ecology of thirteen syntopic species of anurans in a seasonal tropical environment. Oecologia 45:131-141.

Villers-Ruiz, L., AND I. Trejo-VÁZquez. 1998. Impacto del cambio climático en los bosques y areas naturales protegidas de México. Interciencia 23:10-19.

VITT, L.J., AND P.A. ZANI. 2005. Ecology and reproduction of Anolis capito in rain forest of southeastern Nicaragua. Journal of Herpetology 39:36-42.

Received 25 February 2011 Accepted 29 August 2011 
APPENDIX.-Locality data for the specimens examined.

\begin{tabular}{llrr}
\hline Specimen count & Location & Latitude, Longitude & Elevation \\
\hline Anaxyrus debilis & & & \\
31 & Charcos de Risa, Coahuila & $26^{\circ} 12^{\prime} 32.7^{\prime \prime} \mathrm{N}, 103^{\circ} 6^{\prime} 24.0^{\prime \prime} \mathrm{W}$ & $1114 \mathrm{~m}$ \\
1 & Between Sierra de En Medio and & $31^{\circ} 9^{\prime} 51.1^{\prime \prime} \mathrm{N}, 108^{\circ} 34^{\prime} 40.3^{\prime \prime} \mathrm{W}$ & $1427 \mathrm{~m}$ \\
& & & \\
Anaxyrus punctatus & & & \\
5 & Yécora, Sonora & $28^{\circ} 22^{\prime} 4.0^{\prime \prime} \mathrm{N}, 108^{\circ} 55^{\prime} 32.6^{\prime \prime} \mathrm{W}$ & $1545 \mathrm{~m}$ \\
4 & Valle de Tacupeto, Sonora & $28^{\circ} 15^{\prime} 20.5^{\prime \prime} \mathrm{N}, 109^{\circ} 18^{\prime} 1.9^{\prime \prime} \mathrm{W}$ & $435 \mathrm{~m}$ \\
4 & 53 km S, Químicas del Rey, Coahuila & $26^{\circ} 38^{\prime} 44.5^{\prime \prime} \mathrm{N}, 103^{\circ} 9^{\prime} 13.4^{\prime \prime} \mathrm{W}$ & $1084 \mathrm{~m}$ \\
3 & Chínipas, Chihuahua & $27^{\circ} 23^{\prime} 39.9^{\prime \prime} \mathrm{N}, 108^{\circ} 32^{\prime} 36.0^{\prime \prime} \mathrm{W}$ & $469 \mathrm{~m}$ \\
3 & Moris, Chihuahua & $28^{\circ} 8^{\prime} 51.6^{\prime \prime} \mathrm{N}, 108^{\circ} 31^{\prime} 21.8^{\prime \prime} \mathrm{W}$ & $772 \mathrm{~m}$ \\
2 & Químicas del Rey, Coahuila & $27^{\circ} 0^{\prime} 13.2^{\prime \prime} \mathrm{N}, 103^{\circ} 21^{\prime} 49.8^{\prime \prime} \mathrm{W}$ & $1051 \mathrm{~m}$ \\
1 & General Trias, Chihuahua & $28^{\circ} 25^{\prime} 5.9^{\prime \prime} \mathrm{N}, 106^{\circ} 25^{\prime} 55.4^{\prime \prime} \mathrm{W}$ & $1516 \mathrm{~m}$ \\
1 & $27^{\circ} 23^{\prime} 4.3^{\prime \prime} \mathrm{N}, 108^{\circ} 32^{\prime} 27.5^{\prime \prime} \mathrm{W}$ & $470 \mathrm{~m}$ \\
Incilius mazatlanensis & & \\
6 & Las Borregas, Chínipas, Chihuahua & $28^{\circ} 15^{\prime} 200.5^{\prime \prime} \mathrm{N}, 109^{\circ} 18^{\prime} 1.9^{\prime \prime} \mathrm{W}$ & $435 \mathrm{~m}$ \\
5 & Valle de Tacupeto, Sonora & $28^{\circ} 22^{\prime} 4.0^{\prime \prime} \mathrm{N}, 108^{\circ} 55^{\prime} 32.6^{\prime \prime} \mathrm{W}$ & $1545 \mathrm{~m}$ \\
4 & Yécora, Sonora & $27^{\circ} 23^{\prime} 39.9^{\prime \prime} \mathrm{N}, 108^{\circ} 32^{\prime} 36.0^{\prime \prime} \mathrm{W}$ & $469 \mathrm{~m}$ \\
3 & Chínipas, Chihuahua & $28^{\circ} 12^{\prime} 20.9^{\prime \prime} \mathrm{N}, 108^{\circ} 31^{\prime} 36.7^{\prime \prime} \mathrm{W}$ & $794 \mathrm{~m}$ \\
3 & Santa María, Moris, Chihuahua & $30^{\circ} 59^{\prime} 40.7^{\prime \prime} \mathrm{N}, 109^{\circ} 33^{\prime} 22.4^{\prime \prime} \mathrm{W}$ & $1136 \mathrm{~m}$ \\
& Between Fronteras and Esquela, & & \\
\hline
\end{tabular}

